\title{
Impact of Forensic Accounting Domains on Financial Corruption in Lebanon - An Empirical Study
}

\author{
Nader Abou-Zeid ${ }^{1}$, Hasan El-Mousawi ${ }^{2} \&$ Joumana Younis $^{3}$ \\ ${ }^{1}$ Jinan University, Tripoli, Lebanon \\ ${ }^{2}$ Lebanese University, Beirut, Lebanon \\ ${ }^{3}$ Jinan University, Dean of Faculty of Business, Tripoli, Lebanon \\ Correspondence: Hasan El-Mousawi, Prof., Faculty of Economics and Business Administration, Lebanese \\ University, Beirut, Lebanon. Tel: 961-1328-1831.E-mail: hasan.almousawi@ul.edu.lb
}

Received: June 26, 2020

Accepted: July 11, 2020

Online Published: July 15, 2020

doi:10.5539/ijef.v12n8p121

URL: https://doi.org/10.5539/ijef.v12n8p121

\begin{abstract}
Forensic accounting was developed after the widespread corruption in the world of business today. It is now considered a fundamental branch of accounting since it revolves around disputes and issues in the law that require accounting and legal knowledge and practices to be resolved. This study examines the impact of two forensic accounting domains - the expert witness and litigation support - on financial corruption in Lebanon. The study adopts the analytical descriptive approach utilizing an empirical study. A well-structured five-point Likert style questionnaire was devised as the study tool and was distributed among a sample of 323 of the total population that consists of all certified public accountants (CPAs) in Lebanon, tax controllers, senior tax controllers, and heads of the departments and divisions in the Lebanese Ministry of Finance, and auditors at the Lebanese Audit Bureau. The study reached important findings, mainly that there is an impact of the expert witness, which is one of the forensic Accounting domains, on curbing financial corruption in Lebanon, and that there an impact of the litigation support, which is one of the forensic Accounting domains, on curbing financial corruption in Lebanon.
\end{abstract}

Keywords: expert witness, financial corruption, forensic accounting, litigation support

\section{Introduction}

\subsection{Background}

In the past few decades, the world of business has witnessed some alarming scandals about large and international companies that have collapsed as a result of corruption, fraud, creative accounting, or other reasons. There are countless occurrences of scandals and frauds that have overwhelmed societies in all times and all countries. These financial frauds and scandals constituted turning points with historical importance. The following list of companies includes just a few examples of well-known financial scandals and/or frauds: Enron, WorldCom, and Xerox in the USA, Sanyo Electric in Japan, One.Tel and HIH Insurance in Australia, Hugo Boss and Zapf Creation in Germany, Bangkok Bank of Commerce in Thailand, Global Trust Bank in India, and Parmalat in Italy. Besides, there was an increasing number of bankruptcies and financial crimes in the selected nations and in other nations worldwide. Some major auditing firms were accused of manipulating the companies' records employing certain accounting methods that feign the information to be presented to parties of interest. Also, many administrations of companies try to improve their financial situations in profits or financial positions by simply 'decorating' their financial information. This negatively affects the credibility and integrity of the manipulated financial documents on one hand and increases the rate of lawsuits on the other. From all this arises the urgent need for experts who can use their experience and investigative skills to give their opinion about lawsuits relative to fraud and corruption. This came to be known as forensic accounting, which is presently the center of interest of accountants and auditors in the legal domain in addition to all users of accounting information. Forensic accounting may be considered one of the most recent domains which holds great opportunities for future needs. It serves as an integrated framework for accounting and law together in order to present more profound investigations that can be related more to lawsuits. Forensic accounting prepares an accountant to be an efficient expert and advisor who can perform investigations that are conducted more 
comprehensively, accurately and profoundly than done by an external auditor. In addition, a forensic accountant's report comes with sufficient legal evidence that may assist in supporting lawsuits, enlightening judicial authorities, and helping them achieve justice.

\subsection{Statement of the Problem}

Nowadays, Lebanon is suffering from corruption which has been prevailing for so many years that extend even to the independence of the nation. The current government is exerting huge efforts to curb financial corruption in Lebanon; thus, there is increasing discussion which calls for forensic accounting as a desperate need, considering the services that it can present in detecting and curbing financial corruption, which would lead to improving the current financial and economic situation in Lebanon.

The main issue that this study tackles is whether or not domains of forensic accounting have an impact on financial corruption in Lebanon. This being the case, the researchers have the following question in mind:

Do forensic accounting domains have an impact on financial corruption in Lebanon?

From the above question, the following sub-questions arise:

1). Is there an impact of the expert witness, which is one of the forensic Accounting domains, on financial corruption in Lebanon?

2). Is there an impact of the litigation support, which is one of the forensic Accounting domains, on financial corruption in Lebanon?

\subsection{Objective of the Study}

The study at hand aims mainly at presenting and analyzing the reality and importance of forensic accounting domains and their role in developing accounting procedures and mechanisms to curb financial and administrative corruption. From this main objective, arise three goals. The first is to study the role that a forensic accountant plays in litigation support and as an expert witness to curb financial and administrative corruption practices. The study also analyzes the role of forensic accounting in developing the mechanisms of accounting practices to curb financial and administrative corruption. The study additionally advises parties of interest and Lebanese courts on their need for this type of accounting.

\subsection{Literature Review}

In their study about curbing corruption using forensic accounting techniques, Suleiman and Ahmi (2018) found forensic accounting to be an appropriate method for investigations conducted to curb public sector corruption adequately. They also found that results of forensic accounting investigations are suitable to be presented in courtrooms in prosecution and conviction of corrupt personnel. The study additionally identifies a need to augment the competence of the forensic examiners through continuous training as well as through the prerequisite of the latest IT equipment and techniques in addition to the forensic accountants' personal traits suitable for the profession.

Kingsly (2015) examined the principal task of forensic accountants and stated that it is to inspect fraud in financial records. The study suggested that auditors are fact witnesses while forensic accountants can be expert witnesses, and they can testify in courts of law as the prosecution or the defense alike. The study examined the role of forensic accountants in curtailing the nuisance of fraud and corruption in developing countries, and the results show that forensic accountants can play an important role in that crucial matter. The findings of the study also assert that forensic accountants have a complementary role to the governments' agencies which fight corruption and fraud in strategies and policies to curb corruption in the nation.

Okoye and Ndah (2019) showed that there is an association between fraud investigation and fraud detection and prevention. Their study showed a relation between fraud litigation practices and the prevention of fraud. From the findings of the study, the researchers concluded that fraud investigation practices are imperative to avoid fraud in organizations. Likewise, fraud litigation practices constitute a significant aspect in preventing fraud. Consequently, the researchers recommended that organizations enhance their forensic accounting practices in order to curtail fraud. It is possible by conducting forensic auditing of financial records regularly. They also recommended that organizations make sure that all personnel suspected or involved in fraud should be investigated and prosecuted promptly, and this should be done openly to serve as prevention to others in the future.

In their study, Okoye and Gbegi (2013) found that using forensic accounting reduces fraud cases considerably. They also found that there exists a significant difference between professional forensic accountants and traditional auditors, and therefore, the services that forensic accountants can offer may better help in detecting 
and curtailing fraud cases in organizations. As such, the researchers suggested that external auditors should be replaced with forensic accountants and that proper and continuous training on forensic accounting should be provided to the personnel who are responsible for control. The researchers also recommended that the targeted personnel should also be trained to abide by accounting and auditing standards in all their work.

Utomwem et al. (2015) examined the role of forensic accounting in mitigating financial crimes in Nigeria. The study reveals that there exists an urgent need for forensic accountants in the banking system in Nigeria since it is an effectual device in tackling financial crimes that prevail in the banking system at that time. The study also depicts that traditional accounting techniques do not effectively curtail financial crimes. The researchers recommend that corporations in Nigeria should require services that forensic accountants can provide since this domain of accounting presently appears to be a strategic and dynamic tool to tackle all types of financial crimes.

Kasum (2009) presented a conference paper during the proceedings of The First International Conference on Governance, Fraud, Ethics, and Social Responsibility in which he examined financial crimes in developing countries. The results of the reviews assured that fraud and corruption are the primary issues that the third world countries suffer from. The study found that the forensic accountant has an important role to play in curbing financial crimes, more specifically, in the public sector. The study recommended using forensic accounting services in the public sector of developing nations' economies in order to eradicate financial crimes and fraud.

In their study, Okoye et al. (2011) found that forensic accounting supplies an analysis that is considered sustained at a court of law and can be the foundation for negotiations and resolution of disputes. As such, forensic accountants can be ideal for testimonies in court. The researchers stated that the increasing number of fraudulent behavior around the world highlighted the urgent need for forensic accounting as it tackles financial corruption and fraud. Forensic accountants are involved in criminal issues that normally come as a result of fraud or issues that result from an actual or expected dispute or litigation. The study identified the role of forensic accountants in investigations relative to fraud and litigation support such as tax, loss resulting from the breach of contract, quantifying economic damage, being expert witnesses, presenting evidence in legal proceedings, obtaining documents that sustain or disprove allegations, and assistance in settling negotiations between conflicting parties.

Dada (2014) determined that there is a need to apply forensic accounting to examine and discover cases of corruption. Court systems in Nigeria need to be enhanced so that efforts of the Economic and Financial Crimes Commission (EFCC) thrive since the commission does not entail a forensic investigation and accounting unit so appropriate investigation of corruption cannot be conducted. The study recommended that the EFCC create a forensic accounting unit to train experts who would help in investigations, gathering information and proper documents, and in presenting evidence to the court. The study determined that forensic accounting is becoming more popular around the world in presenting evidence that help in the proceedings of court trials prosecuting corruption and help in resolving disputes as forensic accounting entails investigative accounting and litigation support.

In their study, (Oyedokun \& Akinwumi, 2018) indicated that forensic accounting skills have positive effects on corruption eradication. They also determined that if investigators, cross-examiners and those who tackle anti-corruption issues obtain forensic accounting skills, corruption can be decreased. The study suggested that accountants, auditors, and investigators supply themselves with forensic accounting skills in order to help eradicate corruption.

Hashem et al. (2018) investigated the function of forensic accounting in fighting and decreasing financial corruption. Their study also emphasized the fraudulent practices that lead to financial corruption and determined forensic accounting techniques that fight it. They stated that forensic accounting has recently gained increased importance that contributes to areas such as legal consulting, litigation support, business valuation, money laundering, financial corruption, fraud prevention, and more. Their study pointed out that forensic accounting is a must and governments should include it in the curriculum of the accounting departments in universities and institutes of accounting to increase awareness of forensic accounting.

Siam and Abdulla (2019) identified the extent of applying techniques of forensic accounting in Jordan, the impact of applying these techniques in detecting management practices, and reducing them in companies. It also identified the impediments that may bound applying forensic accounting techniques in detecting management practices by certified accountants in Jordan. The study results showed a high application of forensic accounting techniques by the certified accountants in Jordan, a high impact in detecting management practices, low presence of impediments that may bound applying forensic accounting techniques in detecting management practices by certified accountants in the Jordanian shareholding companies. 
There were a lot of studies in the literature that tackle the impact of forensic accounting on curbing corruption and fraud. However, these studies did not go through the details incorporating forensic accounting, such as the domains of forensic accounting; rather, they tackled the role of forensic accounting as a whole in curbing fraud and corruption. In this paper, the researchers examine the impact of forensic accounting domains of the expert witness and litigation support on financial corruption in Lebanon. This study is the first of its kind in Lebanon as far as the researchers know.

\subsubsection{Concept of Forensic Accounting}

As a result of the corruption in the world of business today, forensic accounting which is a modern accounting domain was devised. It came to be considered a fundamental domain of accounting since its field of interest revolves around issues in the law that require accounting practices and techniques to be settled. Other than forensic accounting, it is referred to as financial forensics, forensic accountancy, and investigative accounting.

The American Institute of Certified Public Accountants (American Institute of Certified Public Accountants (AICPA, 2020) set forth a definition of forensic accounting. It states that forensic accounting involves implementing analytical skills and special knowledge which Certified Public Accountants acquire to collect evidence, study and evaluate it. It also entails comprehending their findings and corresponding them in a courtroom, boardroom, or other legal or organizational settings (par. 1). Forensic accounting can also be defined as the scientific accounting procedure used to detect, interpret, analyze and present issues that are relative to deceitful and fraudulent practices in a process acceptable in courts of law (Okoye \& Gbegi, 2013). Forensic accounting is also referred to as the process of using accounting information and information from other sources to determine facts objectively in a way to support action in a court of law (Hopwood et al., 2008). It is also defined as an integration of accounting and auditing skills with investigative skills (Blessing, 2015).

\subsubsection{Importance of Forensic Accounting}

The widespread fraud cases, financial and commercial lawsuits that have a negative impact on the credibility and trust in dealing with such domains have contributed to the emergence of the profession of forensic accounting. The services it presents can support credibility to financial operations in addition to settling financial and commercial disputes in relevant courts in all stages of investigation and data collection leading to an objective and professional opinion based on substantial evidence that helps the court reach judicious verdicts.

Forensic accounting is the need of the hour all over the world. There is an urgent need for internal controls, one of which relates to financial supervision in order to exercise good corporate governance successfully. Unfortunately, the vast number of frauds that have repeatedly been committed raised serious questions as to whether these traditional financial controls work. Doubts about whether or not audit-reporting provides practical financial supervision and the acceptance of accounting methods based on principles have the prospective to create a new approach to risk assurance. Forensic accounting practices which include forensic auditing is the best alternative for detecting and reducing financial malpractices in a principle-based accounting world (Smith \& Crumbley, 2009).

Forensic auditing, one of the forensic accounting practices, has improved the accountability of organizations, strengthened the independence of external auditors, and assisted members of audit committees in performing their function in supervision by providing assurance on the internal audit report, which has a positive impact towards corporate governance. This has decreased fraud and malfeasance related to taxes (Omodero \& Enyioko, 2015).

Corruption and other financial and economic crimes contribute strongly to curbing development efforts. It was concluded that forensic accounting can supply legal support services in lawsuits with appropriate services in the law courts. Also, forensic accounting can establish corporate governance in the public sector which can increase confidence not only in the government but also in the entire system. Corruption and financial crimes create a bad and distorted image of the country both locally and in the international community, which discourages investments (Adegbie \& Fakile, 2012).

\subsubsection{Domains of Forensic Accounting}

Forensic accounting is one of the most modern domains in accounting. It incorporates both accounting and law by giving legal procedures access to the vast accounting information. The main purpose of forensic accounting is presenting facts about the validity of financial information presented to the court in order to come up with reports that guide the law to pronounce fair verdicts to relative parties.

The domains of forensic accounting include, but not restricted to the following (Oseni, 2017; Krstic, 2009): 
- Assisting in legal proceedings by presenting evidence.

- $\quad$ Playing the role of an expert witness.

- Assisting in and attending the investigation for the detection of malpractice, including the formulating questions and inquiries to be posed during questioning stages concerning the financial evidence available.

- Investigating evasions of taxes or other financial commitments or malpractices in accounting records.

- Assisting in concluding deliberations and negotiations between conflicting parties.

- Communicating results of investigations conducted in the form of a report and supporting them with proper documents.

- Attending court trials to hear the statements of the rival expert and providing help with cross- investigation, and questioning.

- Reviewing the damages reports of the rival expert and reporting on both the advantages and disadvantages of the positions taken.

- $\quad$ Assisting in getting necessary documents that sustain or disprove allegations.

Based on the above, it is evident that the domains of forensic accounting are broad, varied and cover all crimes relative to financial corruption and other related systematic crimes such as business and tax conflicts, reimbursement cases related to insurance and professional negligence incidents, intellectual property rights, and other criminal and economic crimes. This study examines forensic accounting services in legal cases, thus the researchers limited the study to two domains: the expert witness and litigation support.

\subsubsection{The Expert Witness}

This is where a forensic accountant provides his opinion to proceedings of a court. It is the responsibility of a forensic accountant to assess the rival experts' professional performance and accountability, examine accounting records relative to the case at hand, and assess economic loss that one of the conflicting parties may be inflicted with (Enofe et al., 2017). According to the American Institute of Certified Public Accountants (AICPA, 2020), the expert witness is the qualified person who can disclose his/her opinion in court proceedings. Forensic accountants are assigned by legal parties to present their opinions in financial or fraud cases. Thereby, the forensic accountants are summoned by legal authorities to testify about the results of their investigations. If they are summoned by the defense, they present their opinion regarding the quality of the results as to whether or not the financial statements presented by the auditor truly reflect the actual position of the relative organization. Forensic accountants can play the role of the expert witness in financial lawsuits considering the adequate qualifications and expertise they possess, in addition to their skills and personal traits that are required to perform their task as effective players in the litigation team. As such, not only should forensic accountants have full knowledge of Generally Accepted Accounting Principles but also be up to date with all circulars relative to their profession. Some of these personal traits include integrity and reliability, ability to work in a team, professional reputation, behavioral and professional conduct, and others (Bhasin, 2013).

\subsubsection{Litigation Support}

The Forensic accountant can help legal authorities in the proceedings of a lawsuit or in defending one in addition to giving presentations about economic issues relative to the lawsuit. Forensic accountants may often be asked to provide solutions to legal conflicts before going to court (Bassey et al., 2017). In addition, the forensic accountants can assist in obtaining documents necessary to sustain or disprove allegations, present them determining the loss, and giving a preliminary assessment of the case at hand. They can also attend and assist in interrogation in addition to formulating more questions and inquiries to be posed during examination for discovery stage concerning the financial evidence available. Moreover, they can review the damages reports of the rival expert and report on both the advantages and disadvantages of the positions taken. They can help in settling discussions and negotiations before and /or after trials (Oyedokun, 2013).

Throughout the world, corruption exists in both developed and developing countries alike. In Lebanon, the chance of corruption is very prevalent. It has been one of the most devastating issues facing our country ever since independence, even before. Corruption is presently the nuisance of Lebanon and has been so for many years. Even with the huge efforts of the present government, news of corruption is still very frequently heard. Thus, there is an increasing need for the use of the services that forensic accounting can present to the government, organizations and individuals alike in order to detect and curb corruption. 


\subsection{Hypothesis}

Based on the research problem, the questions mentioned above and the previous studies, the researchers have the following hypothesis to prove or disprove:

$\mathrm{H}_{1}$. There is an impact of Forensic Accounting domains on financial corruption in Lebanon at the significance level $(\boldsymbol{\alpha}=0.05)$.

From this main hypothesis, two sub-hypotheses arise:

$H_{1.1}$ There is an impact of statistical significance at the level $(\alpha=0.05)$ of the expert witness, which is one of the forensic Accounting domains, on financial corruption in Lebanon.

$H_{1.2}$ There is an impact of statistical significance at the level $(\alpha=0.05)$ of the litigation support, which is one of the forensic Accounting domains, on financial corruption in Lebanon.

\section{Methodology}

\subsection{Population and Sample Selection}

The population of the research consists of all certified public accountants (CPAs) in Lebanon, tax controllers, heads of the departments of income tax in Beirut, tax-payer service, data processing, major taxpayers, protests, tax liability, the audit department at the regional financial division in Mount Lebanon, and auditors at the Lebanese Audit Bureau. The researchers chose a random sample of 323 people from the population and distributed the questionnaire among them in May 2020, all of which responded and were valid for testing and analysis. The demographic data of the sample is shown below:

Table 1. Participants' distribution according to certificate held

\begin{tabular}{lcc}
\hline Education & Number & Percentage \\
\hline Bachelor & 182 & 56.4 \\
Masters & 126 & 39.0 \\
Ph.D. & 15 & 4.6 \\
Total & $\mathbf{3 2 3}$ & $\mathbf{1 0 0 . 0}$ \\
\hline
\end{tabular}

It is evident from the above table that $56.4 \%$ of the sample have a Bachelor's degree, $39 \%$ have a Master's degree, and $4.6 \%$ have PhDs.

Table 2. Participants' distribution according to job position

\begin{tabular}{lcc}
\hline Job position & Number & Percentage \\
\hline Auditor & 213 & 65.9 \\
Auditor at the Lebanese Audit Bureau & 8 & 2.5 \\
Tax Controller & 62 & 19.2 \\
Senior Tax Controller & 29 & 9.0 \\
Head of a division at the Ministry of Finance & 4 & 1.2 \\
Head of a department at the Ministry of Finance & 7 & 2.2 \\
Total & $\mathbf{3 2 3}$ & $\mathbf{1 0 0 . 0}$ \\
\hline
\end{tabular}

It is evident from the table above that $65.9 \%$ of the sample are private auditors and members of the Lebanese Association of Certified Public Accountants (LACPA), 19.2\% are tax controllers, $9 \%$ are senior tax controllers, $2.5 \%$ are auditors at the Lebanese Audit Bureau, 2.2\% are heads of a department at the Ministry of Finance, and $1.2 \%$ are heads of a division at the Ministry of Finance.

Table 3. Participants' distribution according to years of experience

\begin{tabular}{lcc}
\hline Years of experience & Number & Percentage \\
\hline Less than 5 years & 29 & 9.0 \\
$\mathbf{5}$ to 9 years & 47 & 14.5 \\
$\mathbf{1 0}$ to 14 years & 76 & 23.5 \\
$\mathbf{1 5}$ to 19 years & 79 & 24.5 \\
$\mathbf{2 0}$ to 24 years & 41 & 12.7 \\
More than 25 years & 51 & 15.8 \\
Total & $\mathbf{3 2 3}$ & $\mathbf{1 0 0 . 0}$ \\
\hline
\end{tabular}


It is evident from the table above that $9 \%$ have less than 5 years of experience, $14.6 \%$ have 5 to 9 years of experience, while $76.5 \%$ of the sample have more than 10 years of experience in their profession. This denotes that the sample responses are reliable.

Table 4. Participants' distribution according to major

\begin{tabular}{lll}
\hline Major & Number & Percentage \\
\hline Accounting and Audit & 274 & 84.8 \\
Business Administration & 36 & 11.1 \\
Banking and Finance & 11 & 3.4 \\
Law & 1 & 0.3 \\
Management Information System & 1 & 0.3 \\
Total & $\mathbf{3 2 3}$ & $\mathbf{1 0 0 . 0}$ \\
\hline
\end{tabular}

It is evident from the table above that $84.8 \%$ of the sample have Accounting and Audit majors, $11.1 \%$ have majored in Business Administration, 3.4\% have majored in Banking and Finance, 0.3\% have majored in Law, and $0.3 \%$ have majored in Management Information System.

\subsection{Instrumentation}

The study tool used a five-point Likert style and the following table shows the scale range.

Table 5. The Scale ranges of the five-point Likert style (Mean)

\begin{tabular}{lccc}
\hline No. & Response & \multicolumn{2}{c}{ Range } \\
\cline { 3 - 4 } & & From & To \\
\hline $\mathbf{1}$ & Strongly Agree & 4.21 & 5 \\
$\mathbf{2}$ & Agree & 3.41 & 4.20 \\
$\mathbf{3}$ & Neutral & 2.61 & 3.40 \\
$\mathbf{4}$ & Disagree & 1.81 & 2.60 \\
$\mathbf{5}$ & Strongly Disagree & 1.00 & 1.80 \\
\hline
\end{tabular}

\subsection{Validity and Reliability}

Findings of the current study show that Cronbach's Alpha and the Split-Half Coefficient for all the items of the questionnaire are as shown in the table below:

Table 6. Cronbach's Alpha and Split-Half Coefficient

\begin{tabular}{lcccc}
\hline \multirow{2}{*}{ Domains } & \multicolumn{2}{c}{ Cronbach's Alpha } & \multicolumn{2}{c}{ Split-Half } \\
\cline { 2 - 5 } & No. of Items & Cronbach's Alpha & Correlation Coefficient & Guttman Split-Half Coefficient \\
\hline First & 11 & 0.840 & 0.801 & 0.863 \\
Second & 10 & 0.883 & 0.849 & 0.918 \\
Third & 10 & 0.800 & 0.665 & 0.799 \\
All Domains & 31 & 0.917 & 0.928 & 0.927 \\
\hline
\end{tabular}

It is evident from the above table that Cronbach's Alpha for all domains is 0.917 and the Split-Half Coefficient is 0.927 . This means that the study tool has a high level of validity and reliability.

\section{Testing and Discussing the Hypothesis}

\subsection{Data Analysis}

To measure the impact of the expert witness and the litigation support, which are forensic Accounting domains, on curbing financial corruption in Lebanon the researchers used the Mean, Standard Deviation, Relative Weight, One-Sample T-Test, Significance, and rank. The results are shown in the following tables (7), (8), and (9): 
Table 7. Statistical analysis of the first domain (The Expert Witness)

\begin{tabular}{|c|c|c|c|c|c|c|c|}
\hline No. & Item & Mean & Std. Dev. & Rel. Wt. & T-Test & Sig. & Rank \\
\hline 1 & $\begin{array}{l}\text { Writing and presenting reports about investigations relative to financial issues } \\
\text { at court. }\end{array}$ & 4.05 & .676 & $81.0 \%$ & 27.90 & .000 & 9 \\
\hline 2 & $\begin{array}{l}\text { Assisting in understanding financial issues relative to the case by formulating } \\
\text { questions related to collecting financial evidence. }\end{array}$ & 4.30 & .691 & $86.0 \%$ & 33.81 & .000 & 1 \\
\hline 3 & $\begin{array}{l}\text { Presenting damage reports and disclosing strengths and weaknesses in } \\
\text { financial systems and helping in settlement negotiations. }\end{array}$ & 4.13 & .773 & $82.6 \%$ & 26.26 & .000 & 4 \\
\hline 4 & $\begin{array}{l}\text { Providing counsel to settle disputes resulting from professional responsibility } \\
\text { and analyzing and assessing business transactions. }\end{array}$ & 3.96 & .827 & $79.2 \%$ & 20.85 & .000 & 11 \\
\hline 5 & Providing strategies necessary to curb fraud and corruption in organizations. & 4.01 & .911 & $80.2 \%$ & 19.92 & .000 & 10 \\
\hline 6 & $\begin{array}{l}\text { Assessing organizations in case of a dispute that requires studying some } \\
\text { disputable items in several periods. }\end{array}$ & 4.15 & .714 & $83.1 \%$ & 29.06 & .000 & 3 \\
\hline 7 & Providing financial guidance in strategic financial cases, facts, and issues. & 4.06 & .835 & $81.2 \%$ & 22.84 & .000 & 8 \\
\hline 8 & $\begin{array}{l}\text { Examining and analyzing reasons for loss and approximating loss in case of } \\
\text { claiming compensation from insurance companies. }\end{array}$ & 4.07 & .816 & $81.5 \%$ & 23.67 & .000 & 6 \\
\hline 9 & $\begin{array}{l}\text { Approximation of actual value of organizations in case of a merger, take-over, } \\
\text { or liquidation. }\end{array}$ & 4.10 & .768 & $81.9 \%$ & 25.64 & .000 & 5 \\
\hline 10 & Setting proper standards to curtail financial and administrative corruption. & 4.07 & .910 & $81.5 \%$ & 21.10 & .000 & 6 \\
\hline 11 & $\begin{array}{l}\text { Identifying gaps in the financial system through which manipulations can } \\
\text { occur. }\end{array}$ & 4.17 & .770 & $83.3 \%$ & 27.24 & .000 & 2 \\
\hline \multicolumn{2}{|c|}{ Total } & 4.10 & .505 & $81.9 \%$ & 39.02 & .000 & \\
\hline
\end{tabular}

It is evident from the above table that the mean for the sample's responses for the domain is 4.1, which is greater than the neutral value (3). The standard deviation is 0.505 and the relative weight is $81.9 \%$. Also, the value of the calculated T-Test is 39.02 , which is greater than the value of tabular $\mathrm{T}$ at the significance level 0.05 . This denotes the positive attitude of the sample toward the expert witness.

Table 8. Statistical analysis of the second domain (Litigation Support)

\begin{tabular}{|c|c|c|c|c|c|c|c|}
\hline No. & Item & 6 & Std. Dev. & Rel. Wt. & T-Test & Sig. & Rank \\
\hline 1 & Conducting criminal investigations and collecting evidence in financial crimes. & 3.93 & .886 & $78.6 \%$ & 18.91 & .000 & 7 \\
\hline 2 & Investigating financial and administrative corruption. & 4.14 & .832 & $82.8 \%$ & 24.62 & .000 & 1 \\
\hline 3 & $\begin{array}{l}\text { Resolving disputes that arise between stockholders and management related to } \\
\text { financial and administrative corruption. }\end{array}$ & 3.95 & .800 & $78.9 \%$ & 21.28 & .000 & 6 \\
\hline 4 & $\begin{array}{l}\text { Lawsuits related to financial crimes related to electronic accounting information } \\
\text { systems. }\end{array}$ & 4.10 & .790 & $82.0 \%$ & 25.01 & .000 & 3 \\
\hline 5 & Government investigations in illegal or doubtful financial activities. & 3.96 & .846 & 79.2 & 20.39 & .000 & 5 \\
\hline 6 & Investigating declaration of corporate bankruptcy & 4.11 & .720 & $82.3 \%$ & 27.83 & .000 & 2 \\
\hline 7 & $\begin{array}{l}\text { Executing procedures of liquidation for organizations, estimating liabilities and } \\
\text { payables, and identifying priorities for debt settlement. }\end{array}$ & 4.02 & .851 & $80.3 \%$ & 21.46 & .000 & 4 \\
\hline 8 & $\begin{array}{l}\text { Providing services to settle disputes such as negotiations, reconciliation, } \\
\text { mediation, and arbitration. }\end{array}$ & 3.82 & .909 & $76.3 \%$ & 16.16 & .000 & 9 \\
\hline 9 & $\begin{array}{l}\text { Contribution to settling personal disputes such as determining loss resulting } \\
\text { from car accidents or child and spousal support. }\end{array}$ & 3.72 & .983 & $74.4 \%$ & 13.19 & .000 & 10 \\
\hline 10 & $\begin{array}{l}\text { Providing post-dispute services such as capital accounts, shares, profit } \\
\text { allocation, and inheritance. }\end{array}$ & 3.87 & .886 & $77.4 \%$ & 17.66 & .000 & 8 \\
\hline \multicolumn{2}{|c|}{ Total } & 3.96 & .553 & $79.2 \%$ & 31.23 & .000 & \\
\hline
\end{tabular}

It is evident from the above table that the mean for the sample's responses for the domain is 3.96 , which is greater than the neutral value (3). The standard deviation is 0.553 and the relative weight is $79.2 \%$. Also, the value of the calculated T-Test is 31.23, which is greater than the value of tabular $\mathrm{T}$ at the significance level 0.05 . This denotes the positive attitude of the sample toward litigation support. 
Table 9. Statistical analysis of the third domain (Curbing Financial Corruption)

\begin{tabular}{|c|c|c|c|c|c|c|c|}
\hline No. & Item & Mean & Std. Dev. & Rel. Wt. & T-Test & Sig. & Rank \\
\hline 1 & $\begin{array}{l}\text { One reason leading to financial corruption is the frail commitment to } \\
\text { accounting transparency and accounting disclosure standards. }\end{array}$ & 4.22 & .640 & $84.5 \%$ & 34.33 & .000 & 6 \\
\hline 2 & $\begin{array}{l}\text { A reason leading to expanding financial corruption lies in satisfaction with } \\
\text { audits and not looking beyond the numbers. }\end{array}$ & 3.99 & .987 & $79.9 \%$ & 18.09 & .000 & 10 \\
\hline 3 & $\begin{array}{l}\text { The main features of financial corruption are confidentiality and the diversity } \\
\text { of methods used to spread corruption. }\end{array}$ & 4.13 & .777 & $82.6 \%$ & 26.13 & .000 & 7 \\
\hline 4 & $\begin{array}{l}\text { Patterns and tools of financial corruption vary with the diversity of parties } \\
\text { involved and domains in which it is practiced. }\end{array}$ & 4.10 & .737 & $82.0 \%$ & 26.81 & .000 & 8 \\
\hline 5 & $\begin{array}{l}\text { Financial corruption has economic implications that negatively impact } \\
\text { economic growth and the level of national income. }\end{array}$ & 4.39 & .728 & $87.8 \%$ & 34.30 & .000 & 1 \\
\hline 6 & $\begin{array}{l}\text { Financial corruption has social implications that lead to disruption in the } \\
\text { employees' social values and conduct. }\end{array}$ & 4.31 & .712 & $86.2 \%$ & 33.08 & .000 & 4 \\
\hline 7 & $\begin{array}{l}\text { Financial corruption has political implications that weaken the state and } \\
\text { brings it vulnerable to foreign forces. }\end{array}$ & 4.28 & .729 & $85.6 \%$ & 31.54 & .000 & 5 \\
\hline 8 & $\begin{array}{l}\text { Procedures that combat financial corruption include transparency and } \\
\text { integrity in financial operations and spreading the culture of maintaining } \\
\text { public money. }\end{array}$ & 4.38 & .688 & $87.7 \%$ & 36.15 & .000 & 3 \\
\hline 9 & $\begin{array}{l}\text { Local and international organizations play an important role in curbing } \\
\text { financial corruption. }\end{array}$ & 4.00 & .825 & $80.1 \%$ & 21.86 & .000 & 9 \\
\hline 10 & $\begin{array}{l}\text { Effective strategies to combat financial corruption include public sector } \\
\text { reforms and legal and judicial reforms. }\end{array}$ & 4.39 & .637 & $7.8 \%$ & 39.14 & .000 & 1 \\
\hline \multicolumn{2}{|c|}{ Total } & 4.22 & .454 & $84.4 \%$ & 48.26 & .000 & \\
\hline
\end{tabular}

It is evident from the above table that the mean for the sample's responses for the domain is 4.22 , which is greater than the neutral value (3). The standard deviation is 0.454 and the relative weight is $84.4 \%$. Also, the value of the calculated T-Test is 48.26 , which is greater than the value of tabular $\mathrm{T}$ at the significance level 0.05 . This denotes the positive attitude of the sample toward curbing financial corruption.

\subsection{Testing the Hypothesis}

The first hypothesis states "There is an impact of statistical significance at the level $(\alpha=0.05)$ of the expert witness, which is one of the forensic Accounting domains, on financial corruption in Lebanon."

To test this hypothesis, the researchers used the Simple Linear Regression analysis. The results came as follows:

Table 10. Impact of the expert witness on financial corruption

\begin{tabular}{|c|c|c|c|c|c|c|c|c|}
\hline \multirow{2}{*}{$\begin{array}{l}\text { Dependent } \\
\text { curbing } \\
\text { corruption }\end{array}$} & \multicolumn{2}{|c|}{ Unstandardized Coefficient } & \multirow{2}{*}{$\begin{array}{l}\text { Standardized } \\
\text { Coefficient } \\
\text { Beta }\end{array}$} & \multicolumn{2}{|c|}{ T-Test } & ANOVA Test & \multirow{2}{*}{$\begin{array}{l}\text { Correlation } \\
\text { Coefficient } \mathbf{R}\end{array}$} & \multirow{2}{*}{$\begin{array}{l}\text { Coefficient of } \\
\text { Determination } \mathbf{R}^{2}\end{array}$} \\
\hline & Coefficients & $\begin{array}{l}\text { Standard } \\
\text { Error }\end{array}$ & & $\begin{array}{l}\text { Value } \\
\text { of } \mathrm{T}\end{array}$ & $\begin{array}{l}\text { Sig. } \\
\text { Level }\end{array}$ & $\begin{array}{l}\text { Value Sig. } \\
\text { of F } \quad \text { level } \\
\end{array}$ & & \\
\hline Fixed & 2.457 & .182 & & 13.51 & .000 & 95.42 .000 & .479 & .229 \\
\hline $\begin{array}{l}\text { Domain of the Expert } \\
\text { witness }\end{array}$ & .430 & .044 & .479 & 9.768 & .000 & & & \\
\hline
\end{tabular}

It is evident from table (10) that the correlation coefficient between the independent variable "the expert witness" and the dependent variable "curbing financial corruption" is 0.479 , which indicates a direct correlation between the two variables. The Coefficient of Determination is 0.229 which is the value that expresses the extent of the explained variance from the dependent variable "curbing financial corruption". This means that the domain of the expert witness succeeded in interpreting $22.9 \%$ of the variation of the dependent variable, while the rest is due to other factors that were not taken into consideration.

The Linear Regression Coefficient is 0.430 , which denotes the impact of the expert witness on financial corruption. To test the significance of this impact, the value of calculated $\mathrm{T}$ is 9.768 , which is greater than tabular $\mathrm{T}$ at the significance level 0.05 . Consequently, there is a positive significance of the domain "the expert witness" on curbing financial corruption, and the value of this impact is $43 \%$. Consequently, the hypothesis which states: 
"There is an impact of statistical significance at the level $(\alpha=0.05)$ of the expert witness, which is one of the forensic Accounting domains, on financial corruption in Lebanon" is accepted.

The impact of the domain "the expert witness" on financial corruption can be formulated as follows:

$\mathrm{Y}=2.457+0.43 \mathrm{X}$

$\mathrm{Y}$ : curbing financial corruption

$\mathrm{X}$ : domain of the expert witness

The second hypothesis states "There is an impact of statistical significance at the level $(\alpha=0.05)$ of the litigation support, which is one of the forensic Accounting domains, on financial corruption in Lebanon."

To test this hypothesis, the researchers used the Simple Linear Regression analysis. The results came as follows:

Table 11. Impact of the litigation support on financial corruption

\begin{tabular}{|c|c|c|c|c|c|c|c|c|c|}
\hline \multirow[t]{2}{*}{$\begin{array}{l}\text { Dependent variable: curbing } \\
\text { financial corruption }\end{array}$} & \multicolumn{2}{|c|}{$\begin{array}{c}\text { Unstandardized } \\
\text { Coefficient } \\
\end{array}$} & \multirow{2}{*}{$\begin{array}{c}\text { Standardized } \\
\text { Coefficient }\end{array}$} & \multicolumn{2}{|c|}{ T-Test } & \multicolumn{2}{|c|}{ ANOVA Test } & \multirow[t]{2}{*}{$\begin{array}{c}\text { Correlation } \\
\text { Coefficient R }\end{array}$} & \multirow{2}{*}{$\begin{array}{c}\text { Coefficient of } \\
\text { Determination } \\
\mathbf{R}^{\mathbf{2}}\end{array}$} \\
\hline & Coefficients & $\begin{array}{l}\text { Standard } \\
\text { Error }\end{array}$ & & $\begin{array}{c}\text { Value of } \\
\mathrm{T}\end{array}$ & $\begin{array}{l}\text { Sig. } \\
\text { Level }\end{array}$ & $\begin{array}{l}\text { Value } \\
\text { of } F\end{array}$ & $\begin{array}{c}\text { Sig. } \\
\text { level }\end{array}$ & & \\
\hline & 2.656 & .161 & & 16.53 & .000 & 96.49 & .000 & .481 & .231 \\
\hline Domain of litigation support & .395 & .040 & .481 & 9.823 & .000 & & & & \\
\hline
\end{tabular}

It is evident from table (12) that the correlation coefficient between the independent variable "the litigation support" and the dependent variable "curbing financial corruption" is 0.481 , which indicates a direct correlation between the two variables. The Coefficient of Determination is 0.231 which is the value that expresses the extent of explained variance from the dependent variable "curbing financial corruption". This means that the domain of the litigation support succeeded in interpreting $23.1 \%$ of the variation of the dependent variable, while the rest is due to other factors that were not taken into consideration.

The Linear Regression Coefficient is 0.395 , which denotes the impact of litigation support on financial corruption. To test the significance of this impact, the value of calculated $\mathrm{T}$ is 9.823 , which is greater than tabular $\mathrm{T}$ at the significance level 0.05 . Consequently, there is a positive significance of the domain "litigation support" in curbing financial corruption, and the value of this impact is $39.5 \%$. Consequently, the second hypothesis which states: "There is an impact of statistical significance at the level $(\alpha=0.05)$ of the litigation support, which is one of the forensic Accounting domains, on financial corruption in Lebanon" is accepted.

The impact of the domain "litigation support" in curbing financial corruption can be formulated as follows:

$\mathrm{Y}=2.656+0.395 \mathrm{X}$

$\mathrm{Y}$ : curbing financial corruption

$\mathrm{X}$ : domain of the litigation support

\section{Conclusions and Recommendations}

The results of the research showed that forensic accounting can play an important role in curbing financial corruption through the domains that it can provide that covers all illegal financial and administrative practices. Forensic accounting works on collecting, analyzing, evaluating, and interpreting evidence relative to financial cases explicitly and present it to parties of interest. This conforms with the study that Oyedokun and Akinwumi (2018) have made, in which they recommended that accountants and auditors should acquire forensic skills and techniques to curb fraud and financial corruption. This result also conforms with the study that Utomwem, et al. (2015) conducted in Nigeria and examined financial corruption in the banking sector. Moreover, the results of the study at hand showed that a lot of external auditors in Lebanon have little awareness about the main concepts of forensic accounting which is an impediment facing the implementation of forensic accounting in Lebanon at present. This result conforms with the study that Dada (2014) conducted to study forensic accounting as a technique to eradicate corruption. Additionally, the study at hand showed a great need for forensic accounting services in Lebanon, considering its important role in settling financial disputes and lawsuits, especially that financial corruption has become a major issue that Lebanon presently suffers from.

Based on the results of the study, the researchers have some worthwhile recommendations, some of which follow: 
- Forensic accounting should be introduced into university curricula by adding a new major under the title of "Forensic Accounting" within the Master's certificate at the faculty of Business Administration.

- Forensic accounting should be adopted as a new profession in Lebanon, and there should be an organization under which all related issues concerning the profession be discussed and properly organized and legalized.

- Awareness campaigns about forensic accounting and practical, professional training should be conducted to all practitioners of accounting to introduce the new profession along with all types and methods of fraud and corruption to enhance their performance in combating financial and administrative corruption spreading in the Lebanese community.

- The Lebanese Association of Certified Public Accountants (LACPA) should make necessary agreements with the Lawyers Community in Lebanon to train accountants on legal methods.

- The Lebanese accounting community should benefit from the experiences of surrounding countries in forensic accounting.

\section{References}

Adegbie, F., \& Fakile, A. (2012). Economic and Financial Crime in Nigeria: Forensic Accounting as Antidote. British Journal of Arts and Social Science, 6(1), 37-50. Retrieved from https://www.academia.edu/27957813/Economic_and_Financial_Crime_in_Nigeria_Forensic_Accounting_a s_Antidote

American Institute of Certified Public Accountants (AICPA). (2020). Forensic Accounting. Retrieved from https://www.aicpa.org/interestareas/forensicandvaluation/resources/litigation.html

Bassey, B., Eyo, B. E., Ahonkhai, A., \& Ebahi, O. (2017). Effect of Forensic Accounting and Litigation Support on Fraud Detection of Banks in Nigeria. IOSR Journal of Business and Management, 19(6), 56-60. https://doi.org/10.9790/487X-1906055660

Bhasin, M. (2013). Survey Of Appropriate Skills Required by the Forensic Accountants: Evidence from a Developing Economy. International Journal of Accounting and Economics Studies, 1(2), 53-73. https://doi.org/10.14419/ijaes.v1i2.1295

Blessing, I. (2015). Empirical Analysis on the Use of Forensic Accounting Techniques in Curbing Creative Accounting. The International Journal of Economics Commerce and Management, 3(1), 1-15. Retrieved from http://ijecm.co.uk/wp-content/uploads/2015/01/3127.pdf

Dada, S. O. (2014). Forensic Accounting Technique: A Means of Successful Eradication of Corruption through Fraud Prevention, Bribery Prevention and Embezzlement Prevention in Nigeria. Kuwait Chapter of Arabian Journal of Business and Management Review, 4(1), 176-186. https://doi.org/10.12816/0018900

Enofe, A. O., Dominic, E. S., Kifordu, A. A., \& Udoh, B. E. (2017). A Qualitative Review of Forensic Accounting and Effective Judicial System in Nigeria. International Journal of Transformations in Business $\begin{array}{llll}\text { Management, } & 7(4), & \text { 59-82. } & \text { Retrieved }\end{array}$ https://www.edouniversity.edu.ng/oer/journal/a_qualitative_review_of_forensic_accounting_and_effective_ judicial_system_in_nigeria

Hashem, H., Saeed, H., \& Dawod, I. (2018). Efficiency of Forensic Accounting Techniques in Combating Administrative and Financial Corruption-An Exploratory Study. The Journal of Administration \& Economics, (117), 257-271. Retrieved from https://www.iasj.net/iasj?func=fulltext\&aId=154777

Hopwood, W., Leiner, J., \& Yonng, G. (2008). Forensic Accounting (1st ed.). Boston: McGraw-Hill/lrwin.

Kasum, A. (2009). The Relevance of Forensic Accounting to Financial Crimes in Private and Public Sectors of Third World Economies: A Study from Nigeria. (Conference Paper) Proceedings of The 1st International Conference on Governance Fraud Ethics and Social Responsibility, June 11-13, 2009. https://doi.org/10.2139/ssrn.1384242

Kingsly, M. (2015). The Role of Forensic Investigation Professionals in the Prevention of Fraud and Corruption in Developing Countries. https://doi.org/10.2139/ssrn.2605811

Krstic, J. (2009). The Role of Forensic Accountants in Detecting Frauds in Financial Statements. Facta Universitatis, 6(3), 295-302. Retrieved from http://facta.junis.ni.ac.rs/eao/eao200903/eao200903-09.pdf

Okoye, E., \& Gbegi, D. O. (2013). Forensic Accounting: A tool for Fraud Detection and Prevention in the Public Sector. (A Study Of Selected Ministries in Kogi State). International Journal of Academic Research in 
Business and Social Sciences, 3(3), 1-19. $\quad$ Retrieved from https://papers.ssrn.com/sol3/papers.cfm?abstract_id=3162992

Okoye, E., \& Ndah, E. N. (2019). Forensic Accounting and Fraud Prevention in Manufacturing Companies in Nigeria. International Journal of Innovative Finance and Economics Research, 7(1), 107-116. Retrieved from https://seahipaj.org/journals-ci/mar-2019/IJIFER/full/IJIFER-M-9-2019.pdf

Okoye, E., Emma, I., \& Ndidika, L. (2009). The Role of Forensic Accounting in Fraud Investigation and Litigation Support. The Nigerian Academic Forum, 17(1), 39-44. Retrieved from https://ssrn.com/abstract $=1788822$

Omodero, C., \& Enyioko, N. (2015). The Relevance of Forensic Audit and Investigation in Resolving Tax-Related Fraud and Malfeasance. https://doi.org/10.2139/ssrn.2640502

Oseni, A. I. (2017). Forensic Accounting and Financial Fraud in Nigeria: Problems and Prospects. Journal of Accounting and Financial Management, 3(1), 23-33. Retrieved from https://iiardpub.org/get/JAFM/VOL.\%203\%20NO.\%201\%202017/FORENSIC\%20ACCOUNTING.pdf

Oyedokun, G. (2013). An Assessment of the Role of Forensic Accountants in Litigation Support Services (An Explanatory Approach). https://doi.org/10.2139/ssrn.2410664

Oyedokun, G. E., \& Akinwumi, O. (2018). Forensic Accounting Skills and Corruption Eradication in Nigeria. Journal of African Interdisciplinary Studies, 2(2), 4-16. Retrieved from https://www.researchgate.net/publication/326191161_FORENSIC_ACCOUNTING_SKILLS_AND_COR RUPTION_ERADICATION_IN_NIGERIA

Siam, W., \& Abdullah, M. (2019). The Effect of Applying Forensic Accounting Techniques in Earnings Management Practices Detection in the Jordanian Shareholding Companies from the Auditors' Perspective. Global Journal of Economics and Business, 7(2), 199-225. https://doi.org/10.31559/GJEB2019.7.2.5

Smith, G. S., \& Crumbley, D. L. (2009). Defining a Forensic Audit. Journal of Digital Forensics, Security and Law, 4(1), 61-80. https://doi.org/10.15394/jdfsl.2009.1054

Suleiman, N., \& Ahmi, A. (2018). Mitigating Corruption Using Forensic Accounting Investigation Techniques: The Watchdog Perspectives. Indian-Pacific Journal of Accounting and Finance, 2(1), 4-25. https://doi.org/10.32890/ipjaf.2018.2.1.38

Utomwen, O., Enofe, O., \& Danjuma, E., (2015). The Role of Forensic Accounting in Mitigating Financial Crimes. International Journal of Commerce and Management Research, 1(1), 40-47. Retrieved from http://www.managejournal.com/archives/2015/vol1/issue1/1-1-22.1

\section{Copyrights}

Copyright for this article is retained by the author(s), with first publication rights granted to the journal.

This is an open-access article distributed under the terms and conditions of the Creative Commons Attribution license (http://creativecommons.org/licenses/by/4.0/). 